\title{
THE ROLE OF INTERMODAL TRANSPORT IN PORT REGIONALISATION
}

This is the pre-published version of the text. The final published paper can be found at:

Monios, J., Wilmsmeier, G. (2013). The role of intermodal transport in port regionalisation. Transport Policy. 30: 161-172.

DOI: 10.1016/j.tranpol.2013.09.010.

\section{JASON MONIOS $\uparrow$ and GORDON WILMSMEIER $\dagger \dagger$}

$\dagger$ Transport Research Institute, Edinburgh Napier University, Merchiston Campus, Edinburgh EH10 5DT, United Kingdom j.monios@napier.ac.uk

$\dagger \dagger$ UNECLAC, Av. Dag Hammarskjold 3477, Vitacura, Santiago, Chile Gordon.wilmsmeier@cepal.org

\begin{abstract}
The port regionalisation concept extended earlier spatial models of port development with a focus on institutional relationships governing the complexity of inland connections. The concept accounts for the fact that modern ports operate in an increasingly complex and sophisticated transport and logistics environment, embedded within multi-scalar planning regimes. This paper addresses the role of intermodal transport in port regionalisation by reviewing the literature on the three core aspects of the concept: intermodal terminals, inland logistics and collective action problems.
\end{abstract}

Results reveal that inland terminals developed by landside actors often experience a conflict of strategy with port actors (either port authorities or terminal operators). Port actors have difficulty acting beyond the port perimeter but some port terminal operators have begun to demonstrate successful investments in inland terminals in order to manage their container throughput more strategically. Inland logistics markets tend to be centralised and focus heavily on domestic flows, thus the efficiency of intermodal freight services is challenged by 
the need to combine port and domestic movements which have different product, route and equipment characteristics. Collective action is an arena where port actors can be influential due to the role of informal networking in managing freight corridors; however, institutional constraints limit their ability to act directly.

The findings in this paper elucidate challenges to the ability of ports to control or capture hinterlands through the strategies of integration that the port regionalisation concept proposes. The paper concludes by proposing a research agenda developing from recent institutional adaptations of port actors as a result of these challenges.

Key words: intermodal transport, planning, container ports, inland terminals, corridors, institutions, logistics, regionalization 


\section{Introduction}

Notteboom and Rodrigue's (2005) port regionalisation concept extended earlier spatial models of port development with a focus on institutional relationships governing the complexity of inland connections. The new approach recognised that modern ports operate in an increasingly complex and sophisticated transport and logistics environment, embedded within multi-scalar planning regimes.

Effective intermodal transport infrastructure and operations are required to underpin the levels of integration required for successful port regionalisation. A large literature on intermodal transport and logistics has been published in recent years ${ }^{1}$; it is the contention of this paper that an analysis of this literature can enable an identification of potential challenges to successful port regionalisation that are not currently addressed.

This paper addresses the role of intermodal transport in port regionalisation. It identifies and examines the processes implicit within the concept; namely, intermodal terminal development, logistics integration strategies and the institutional processes of resolving collective action problems. While port regionalisation covers more than intermodal transport, these three processes are all inextricably linked with the concept because the relevant infrastructure and the integration of dominant industry players provide means to capture or control key corridors and load centres. It is therefore argued that port regionalisation cannot be fully understood (and hence theorised) without greater analysis of the key issues from the intermodal literature.

The paper begins with an examination of port development theory in general and the regionalisation concept in particular. From this analysis, the three key elements of port regionalisation are derived. In section three a conceptual framework is established and an inductive methodology described, based on three open-ended research questions. The three elements are analysed through a review of the literature on both cases and conceptualisations in order to describe and discuss how the integration processes as defined within the port regionalisation concept are enabled or constrained. Following a discussion of these findings in section seven, the paper concludes by proposing a future research agenda relating to the institutional adaptations of port actors as a result of the challenges identified in this paper.

\footnotetext{
${ }^{1}$ While intermodal transport includes container movements by both rail and barge, rail transport is by far the most common topic in the literature. The barge literature (e.g. Choong et al., 2002; Trip \& Bontekoning, 2002; Groothedde et al., 2005; Konings, 2007; Konings et al., 2013) tends to focus on operations rather than terminal development and the institutional aspects of port integration.
} 


\section{The port regionalisation concept}

A number of authors have attempted to explain the complex process of port development by proposing different conceptual models. Early models were primarily focused on spatial analysis, such as the "main street" model of Taaffe et al. (1963) and Bird's (1963) "Anyport" model, which were developed along similar lines by Rimmer (1967) and Hoyle (1968). Hayuth (1981) developed the concept of dominant ports or load centres that increase their inland penetration and hinterland capture, and Barke (1986) produced a similar model, with an additional focus on decentralisation, whereby some port activities are moved from the port to less congested areas. Van Klink (1998) suggested port city, port area and port region as summaries of previous port models, and identified the rise of port networks as a fourth stage in port development, including logistical control of inland access as a new role for the port in this phase of development, particularly related to the integration of activities at noncontiguous sites. Later authors have suggested that simplistic models such as Bird's or the UNCTAD generational model (UNCTAD, 1992) struggle to capture the complexity of port infrastructure, operations and services (Beresford et al., 2004; Bichou \& Gray, 2005; Sanchez \& Wilmsmeier, 2010).

Earlier spatial models of port development have been analysed by previous authors (e.g. Slack, 1993; Slack \& Wang, 2002; Olivier \& Slack, 2006; Lee et al., 2008; Ducruet et al., 2009; Wang \& Ducruet, 2012; Monios \& Wilmsmeier, 2012a). Space restrictions prevent a detailed analysis here; for the purposes of this paper the port regionalisation concept is taken as the starting point. However, the key features of its derivation from Bird (1963) and Taaffe et al. (1963) require some brief explication.

Bird's (1963) model was focused on port installations (e.g. terminal locations which expanded into new deeper water sites and specialised into container and bulk terminals).Notteboom and Rodrigue (2005) condensed Bird's model into three phases (setting, expansion and specialisation) and then added a phase of "port regionalisation", in which transhipment hubs and maritime forelands are incorporated.

Taaffe et al., (1963) examined how inland connections underpin port competition, through the evolution of high-priority corridors between the largest nodes. Notteboom and Rodrigue (2005) expanded the port's role in this hinterland integration model in order to address the rising importance of inland load centres to port development, particularly the integration of inland terminals within the transport network. The regionalisation concept's focus on hinterland integration can be seen as a combination of load centres (Hayuth, 1981) 
and priority corridors (Taaffe et al., 1963). Indeed, some empirical applications of port regionalisation in new contexts (Ducruet et al., 2009; Wang \& Ducruet, 2012) imply in their focus on inland control that the port regionalisation concept's major debt is to Taaffe et al. (1963).

The port regionalisation concept has not been defined adequately. It has been called a phase and a process, an accumulation of various strategies. Notteboom and Rodrigue (2005; p.302) assert:

Port regionalisation thus represents the next stage in port development (imposed on ports by market dynamics), where efficiency is derived with higher levels of integration with inland freight distribution systems. . . Many ports are reaching a stage of regionalisation in which market forces and political influences gradually shape regional load centre networks with varying degrees of formal linkages between the nodes of the observed networks.

Port regionalisation is thus a term that encapsulates a variety of integration and cooperation strategies, with varying motivations of hinterland capture, control and competition.

The term "regionalisation" is generally understood in political discourse to refer to a shift in focus, power or responsibility to the regional level, a process of devolution from the national level. A vast literature exists on issues of "hollowing out" and "filling in" of governance capacity (see section 6), including critiques of the "new regionalism" (Lovering, 1999). However, none of these issues are raised in the port regionalisation discussion. The term appears to be used in the sense that the port's focus moves spatially from a local to a regional focus, a change in emphasis that is reflected in the seeking of new ways of integrating with inland transport systems.

Ducruet (2009) stated that the "port region" has never been defined adequately. Modern ports are embedded in the territorial and economic characteristics of their immediate geographical region while also acting as gateways to the trade of larger regions. Thus the port region is multifaceted, incorporating the local economy, the wider hinterland and the port range. The "region" in the port regionalisation concept can therefore be understood more accurately as the hinterland, which is itself an amorphous concept depending on how integrated a port is with inland transport and logistics networks.

The port regionalisation concept is linked to the "multi-port gateway region" proposed by Notteboom (2010). This concept defines a number of ports competing to serve an overlapping 
hinterland, and intermodal connections as well as suitable logistics structures are paramount to capture and control these areas. Similarly, the regional differences and specificities of each port region, both within and between continents, will determine how regionalisation plays out in terms of terminals, corridors and institutional relationships. Rodrigue and Notteboom (2010) identified globalisation, economic integration and intermodal transport as three major influences on what they call "the regionalism of freight distribution" (p.498), concluding that "regionalism results in different strategies" (p.504), and they have noted elsewhere that "there is no single strategy in terms of modal preferences as the regional effect remains fundamental" (Notteboom and Rodrigue, 2009; p.2).

How, then, is it possible to capture specific "regional effects" or "regionalism" within a concept of "regionalisation", while recognising the unreliable relationship between region and hinterland, and then to convert these somewhat vague concepts into theory? This paper will derive the key elements of the port regionalisation concept to examine in more detail how they reveal such regional effects or "regionalism" through the spatial and institutional characteristics of each activity.

The port regionalisation concept has both spatial and institutional aspects. Spatial refers to physical developments such as terminals and rail/barge corridors. However, an essential component is market capture which is not based on physical developments but institutional relationships; in most cases the infrastructure is common-user so the port authority or terminal cannot control the physical corridors but rather focuses on making agreements for the traffic to come through its port, regardless of who the transport operator is, what mode they use and which corridor they follow. It is thus the shipping line and the shipper's selection of carrier or merchant haulage that exerts significant influence on hinterland cargo flows.

The early port development literature was focused more on spatial development than actor-centric approaches, due in part to the historical industry structure. Recent literature distinguishes between port actors (see below), but insufficient attention has been given to the identification of the different strategies of these actors. Notteboom and Rodrigue (2005; p.302) assert that regionalisation is "imposed on ports" but the dynamics of this concept are unclear, such as the determinants of the "varying degrees of formal linkages" and the way that "market forces and political influences" affect these processes embedded within the concept.

While one paper cannot cover all possibilities, three key aspects will be selected for further study: inland terminals, inland logistics and collective action problems. Each aspect 
will be examined in order to identify how intermodal transport enables or constrains the integration processes embedded within port regionalisation.

\section{Conceptual framework and methodology}

The first key distinction of the port regionalisation concept is its focus on inland terminals. Notteboom and Rodrigue (2005) state that the concept "incorporate[s] inland freight distribution centres and terminals as active nodes in shaping load centre development" (p.299), and that this process is "characterised by strong functional interdependency and even joint development of a specific load centre and (selected) multimodal logistics platforms in its hinterland" (p.300).

The second key aspect of the port regionalisation concept is the role of the market, in particular the changing nature of logistics operations. Notteboom and Rodrigue (2005) state that "regionalisation results from logistics decisions and subsequent actions of shippers and third-party logistics providers" (p.306), and that "the transition towards the port regionalisation phase is a gradual and market-driven process, imposed on ports, that mirrors the increased focus of market players on logistics integration" (p.301). They go on to note that "logistics integration ... requires responses and the formulation of strategies concerning inland freight circulation. The responses to these challenges go beyond the traditional perspectives centered on the port itself" (p.302).

The third key element of port regionalisation to be addressed in this paper is the role of collective action problems. Notteboom and Rodrigue (2005) discuss proactive attempts to influence load centre or inland terminal development, as something of an alternative to their suggestion that port regionalisation is "imposed on ports" (p.301). They state that "the trend towards spatial (de)concentration of logistics sites in many cases occurs spontaneously as the result of a slow, market-driven process. But also national, regional and/or local authorities try to direct this process by means of offering financial incentives or by reserving land for future logistics development" (p.306). Yet they warn against the danger of optimism bias: "a lack of clear insights into market dynamics could lead to wishful thinking by local governments. . . . This can lead to overcapacity situations" (p.307). While the authors suggest that ports should not "act as passive players" (p.306), and should adopt "appropriate port governance structures" (p.306) to deal with these new challenges, they state clearly that "the port itself is not the chief motivator for and instigator of regionalisation" (p.306). However, they note that "the port authority can be a catalyst even when its direct impact on cargo flows is limited" (p.307). Notteboom \& Rodrigue (2005) observe that many different types of relationships can 
be developed between the port and the inland actors, depending largely on "the institutional and legal status of the partners involved" (p.307). Essential to an understanding of this aspect is the uneven distribution of costs and benefits resulting in a free rider problem: "Port authorities are generally aware that free-rider problems do exist. This might make port authorities less eager to embark on direct formal strategic partnerships with a selected number of inland terminals. Instead, port authorities typically favour forms of indirect cooperation ... which are less binding and require less financial means" (p.310) as "a seaport cannot make cargo generated by an inland terminal captive to the port" (p.310).

In summary, according to the port regionalisation concept, inland terminals are active nodes, inland logistics integration is driven by market players and collective action problems can challenge the port's ability to act. The research topics for this study relate to each of these three aspects, the main characteristics of which are listed in Table 1.

Table 1. Three research topics derived from the port regionalisation concept, with main characteristics

\begin{tabular}{|c|c|}
\hline Topic & Main characteristics derived from port regionalisation \\
\hline $\begin{array}{l}\text { Inland terminal } \\
\text { development }\end{array}$ & $\begin{array}{l}\text { - Inland terminals are active nodes } \\
\text { - Functional interdependency between port and inland actor } \\
\text { - Joint developments in the hinterland }\end{array}$ \\
\hline Inland logistics & $\begin{array}{l}\text { - Increasing focus on logistics integration } \\
\text { - Determined by actions of shippers and 3PLs } \\
\text { - Imposed on ports }\end{array}$ \\
\hline Collective action & $\begin{array}{l}\text { - Market-driven but port authority can be a catalyst } \\
\text { - Intervention by public sector is common } \\
\text { - Free rider problem } \\
\text { - Indirect cooperation }\end{array}$ \\
\hline
\end{tabular}

The common thread in all three aspects is integration between port and inland actors, although the varying types and levels are not classified. If port regionalisation is proposed as an observable stage in port development, the implication is that its presence is possible or even probable in the majority of instances. This paper will look at the three key aspects just derived in order to identify how they enable or constrain the level of integration required for true port regionalisation. Moreover, it must be recognised that port regionalisation is not a theory; it does not make predictions that can be formed into hypotheses for testing. A deductive methodology is, therefore, not appropriate, and the research questions for this study are purposely open-ended: 
1. What are the key features of inland terminal development and how can they influence port regionalisation?

2. What are the key features of inland logistics integration and how can they influence port regionalisation?

3. What are the key features of collective action problems and how can they influence port regionalisation?

This study follows an inductive methodology, based on an analysis of existing works (both primary research on cases and secondary theorisations and conceptualisations). In order to examine the three constituent parts of port regionalisation, the paper looks at how each of the three topics have been explored both in actual cases and in theorisations, before drawing conclusions about how both these cases and theorisations can feed back into the concept.

The methodology for this study is to review the literature and to describe and discuss how the integration processes as defined within the port regionalisation concept are enabled or constrained. While cases extant in the literature are discussed in this paper, the findings cannot be deduced from a quantitative analysis of the totality of such cases, as many of the necessary features are not recorded in the case study analyses. Indeed, one difficulty arising from the large literature on hinterland transport in recent years is the many different frameworks under which it has been analysed.

When dividing port regionalisation into its three constituent parts, the first (inland terminal development) is naturally more case-based, therefore will be examined by reviewing the cases in the literature. It must nevertheless be remembered that the cases from the literature are not a random sample to be used in a deductive approach attempting to prove or disprove hypotheses. The cases extant in the literature have been used by the various authors as exemplars of certain types, so they should not be analysed as evidence for or against a hypothesis. The second aspect (logistics integration) relates more to previous work on industry structure and practice with only some case research, therefore the analysis proceeds by establishing the key features of logistics integration to match it against the processes implied for successful port regionalisation. The third aspect (collective action) is an institutional theoretical concept and has naturally been addressed through highly theoretical approaches, the key features of which will be summarised in this paper and compared against the port regionalisation concept. Therefore, to analyse these three aspects of port 
regionalisation necessitates an approach that covers cases, theories, summaries and conceptualisations in a multi-dimensional manner.

\section{The role of inland terminals in port regionalisation}

\subsection{Introduction}

The three major themes in the inland terminal literature are the development process (especially the roles of public and private actors), the operational models vis-à-vis port and rail/barge actors and the role of logistics. While inland logistics will be considered in the following section, the terminal development process and different operational models will be addressed here.

\subsection{The development process of inland terminals}

Table 2 shows that inland terminals can be developed by different organisations, such as public authorities, real estate developers, rail/barge operators, port authorities and port terminal operators. 
Table 2. Examples from the literature of different inland terminal developers

\begin{tabular}{|c|c|c|c|}
\hline & Developer & Name & References \\
\hline \multirow{4}{*}{ Government } & $\begin{array}{l}\text { Fully public } \\
\text { (municipality) }\end{array}$ & Falköping, Sweden & $\begin{array}{l}\text { Bergqvist, 2008; Bergqvist et } \\
\text { al., 2010; Wilmsmeier et al., } \\
\text { 2011; Monios \& } \\
\text { Wilmsmeier, 2012a }\end{array}$ \\
\hline & $\begin{array}{l}\text { Fully public (jointly by } \\
\text { the town, province and } \\
\text { chamber of commerce) }\end{array}$ & Verona, Italy & Monios, 2014 \\
\hline & PPP & Bologna, Italy & Monios, 2014 \\
\hline & $\begin{array}{l}\text { One-off funding grant } \\
\text { or land provision }\end{array}$ & $\begin{array}{l}\text { Uiwang, Korea } \\
\text { Jinhua, China }\end{array}$ & $\begin{array}{l}\text { Hanaoka \& Regmi, } 2011 \\
\text { Monios \& Wang, } 2013\end{array}$ \\
\hline Real estate & Real estate developer & $\begin{array}{l}\text { ProLogis, in } \\
\text { conjunction with } \\
\text { CenterPoint, } \\
\text { developed the BNSF } \\
\text { Logistics Park in } \\
\text { Chicago }\end{array}$ & Rodrigue et al., 2010 \\
\hline \multirow{4}{*}{ Rail operator } & $\begin{array}{l}\text { Ex national rail } \\
\text { operator but now } \\
\text { privatised }\end{array}$ & UK examples & $\begin{array}{l}\text { Monios \& Wilmsmeier, } \\
\text { 2012b }\end{array}$ \\
\hline & $\begin{array}{l}\text { Vertically-separated } \\
\text { and quasi-private but } \\
\text { still nationally-owned } \\
\text { rail operator }\end{array}$ & European examples & $\begin{array}{l}\text { Monios \& Wilmsmeier, } \\
\text { 2012a }\end{array}$ \\
\hline & $\begin{array}{l}\text { Rail operator in } \\
\text { countries where } \\
\text { operations remain } \\
\text { wholly or } \\
\text { predominantly under } \\
\text { state control }\end{array}$ & Concor in India & $\begin{array}{l}\mathrm{Ng} \& \text { Gujar, 2009a\&b; } \\
\text { Gangwar et al., } 2012\end{array}$ \\
\hline & Private rail operator & $\begin{array}{l}\text { Joliet intermodal } \\
\text { terminal Chicago } \\
\text { built by BNSF } \\
\end{array}$ & Rodrigue et al., 2010 \\
\hline \multirow{3}{*}{ Port actor } & Port authority & $\begin{array}{l}\text { Coslada, Spain } \\
\text { Enfield, Sydney }\end{array}$ & $\begin{array}{l}\text { Monios, } 2011 \\
\text { Roso, } 2008 \\
\end{array}$ \\
\hline & & Hidalgo, Mexico & $\begin{array}{l}\text { Rodrigue \& Wilmsmeier, } \\
2013\end{array}$ \\
\hline & Port terminal operator & Venlo, NL & $\begin{array}{l}\text { Van Klink, 1998; Rodrigue } \\
\text { and Notteboom, 2009; Roso } \\
\text { et al., 2009; Monios, 2011; } \\
\text { Veenstra et al., 2012; Monios } \\
\text { \& Wilmsmeier, 2012a }\end{array}$ \\
\hline
\end{tabular}


Developments driven by the public sector due to motivations of regional development are more prevalent in Europe (Tsamboulas et al., 2007; Proost et al., 2011),although state involvement is becoming more common as a risk mitigation strategy in large intermodal schemes in the United States (Rodrigue \& Notteboom, 2012). Questions have been raised regarding the efficacy of public investment in terminals considering the difficulties of economically viable operation once the site is built (Höltgen, 1996; Gouvernal et al., 2005; Proost et al., 2011; Liedtke \& Carillo Murillo,2012).It has been argued that in North America the private sector focus on profit tends to regulate this problem (Notteboom \& Rodrigue, 2009; Rodrigue at el., 2010). On the other hand, public sector developments are more likely to adhere to planning strategies such as location in brownfield sites or economically undeveloped areas. Private sector developments, while technically also subject to the same planning approvals, often succeed in evading such restrictions (Hesse, 2004), partly due to a lack of institutional capacity to manage planning conflicts (Flämig\& Hesse, 2011). Even where local planning rules apply, the lack of a coordinated regional approach can lead to suburban sprawl of logistics platforms (Bowen, 2008; Rahimi et al., 2008;Dablanc \& Ross, 2012), a lack of incentive to invest ( $\mathrm{Ng}$ et al., 2013) or a split of scale economies across institutional jurisdictions (Wilmsmeier et al., 2011). Thus, while ports attempt strategic inland terminal developments to further their competitive goals, the conflicting aims of landside actors to develop terminals based on strategies of regional development leads to an oversupply of terminals and fragmentation of flows, undermining the integration necessary for successful port regionalisation.

According to the cases in the literature, inland terminals developed by a transport operator tend to be rail operators more so than barge. In Europe, most rail networks were managed by the national government until recent times (Martí-Henneberg, 2013), thus terminals were developed both by private transport operators attached to the national network and by the national rail operators themselves. As shown in Table 2, these sites are now mostly owned and/or operated by private operators, or, in a liberalised EU environment, the verticallyseparated and quasi-private but still nationally-owned rail operator. In other countries, the rail operations remain wholly or predominantly under state control. In the United States, where rail is privately owned and operated on a model of vertical integration, intermodal terminals are developed and operated by the private rail companies.

\subsection{The operational models of inland terminals}


As part of an intermodal corridor, inland terminals exhibit different operational models that involve different levels of cooperation, investment and integration with port and rail actors (see Table 3 ).

Table 3. Levels of collaboration and integration in intermodal corridors

\begin{tabular}{|c|c|c|c|}
\hline $\begin{array}{l}\text { External } \\
\text { actor }\end{array}$ & Type & Name & Reference \\
\hline \multirow{3}{*}{$\begin{array}{l}\text { Rail } \\
\text { operators }\end{array}$} & $\begin{array}{l}\text { Intermodal terminal operator } \\
\text { is independent from rail } \\
\text { service operation }\end{array}$ & Azuqueca, Spain & Monios, 2011 \\
\hline & $\begin{array}{l}\text { Intermodal terminal operator } \\
\text { runs rail services for any } \\
\text { users }\end{array}$ & $\begin{array}{l}\text { Freightliner, UK } \\
\text { Delcatrans, Belgium }\end{array}$ & $\begin{array}{l}\text { Monios \& Wilmsmeier, } \\
\text { 2012a\&b } \\
\text { Monios \& Wilmsmeier, } \\
\text { 2012a\&b }\end{array}$ \\
\hline & $\begin{array}{l}\text { Intermodal terminal operator } \\
\text { runs rail services directly for } \\
\text { the site tenants }\end{array}$ & $\begin{array}{l}\text { Venlo, NL } \\
\text { Minto, Sydney }\end{array}$ & $\begin{array}{l}\text { Van Klink, 1998; Rodrigue } \\
\text { and Notteboom, 2009; Roso } \\
\text { et al., 2009; Monios, 2011; } \\
\text { Veenstra et al., 2012; } \\
\text { Monios \& Wilmsmeier, } \\
\text { 2012a } \\
\text { Roso, } 2008\end{array}$ \\
\hline \multirow{4}{*}{$\begin{array}{l}\text { Port } \\
\text { authorities } \\
\text { and terminal } \\
\text { operators }\end{array}$} & $\begin{array}{l}\text { Investment from port } \\
\text { authority }\end{array}$ & $\begin{array}{l}\text { Coslada, Spain } \\
\text { Enfield, Sydney }\end{array}$ & $\begin{array}{l}\text { Monios, } 2011 \\
\text { Roso, } 2008\end{array}$ \\
\hline & & Hidalgo, Mexico & $\begin{array}{l}\text { Rodrigue \& Wilmsmeier, } \\
2013\end{array}$ \\
\hline & $\begin{array}{l}\text { Investment from port terminal } \\
\text { operator }\end{array}$ & Venlo, NL & $\begin{array}{l}\text { Van Klink, 1998; Rodrigue } \\
\text { and Notteboom, 2009; Roso } \\
\text { et al., 2009; Monios, 2011; } \\
\text { Veenstra et al., 2012; } \\
\text { Monios \& Wilmsmeier, } \\
\text { 2012a }\end{array}$ \\
\hline & $\begin{array}{l}\text { Port actors are directly } \\
\text { involved in establishing } \\
\text { intermodal services or } \\
\text { corridors }\end{array}$ & $\begin{array}{l}\text { Barcelona } \\
\text { Alameda Corridor }\end{array}$ & $\begin{array}{l}\text { Van den Berg et al., 2012; } \\
\text { Jacobs, 2007; Rodrigue \& } \\
\text { Notteboom, 2009; Monios } \\
\text { \& Lambert, 2013; } \\
\text { Notteboom \& Rodrigue, } \\
2009\end{array}$ \\
\hline
\end{tabular}


Table 3 shows that the intermodal terminal operator may be independent from rail service operation, it may run rail services for any users or it may run rail services directly for the site tenants. Bergqvist et al. (2010) noted that terminal volume is reliant on traffic flows therefore the terminal operator requires a close relationship if not some level of integration with the rail operator(s) to guarantee traffic coming to the terminal.

From a port perspective, there may be investment from a port actor, whether a public port authority or a private port terminal operator. This investment may be simply a shareholding or may be direct involvement with an extended gate type operation, a specific kind of intermodal service whereby the port and the inland node are operated by the same operator, managing container flows within a closed system, thus achieving greater efficiency (e.g. Venlo - see Van Klink, 1998; Rodrigue and Notteboom, 2009; Roso et al., 2009; Monios, 2011; Veenstra et al., 2012; Monios \& Wilmsmeier, 2012a). Similarly, port actors can be directly involved in establishing intermodal services or corridors.

Academic literature over the past decade has begun to develop conceptual models to classify and analyse different strategies of inland terminal development, with a dominant focus on Europe and the United States (e.g. Rodrigue \& Notteboom 2009; Roso et al. 2009; Bergqvist et al. 2010; Rodrigue et al. 2010; Monios \& Wilmsmeier 2012a). While in recent years some literature on Asia (e.g. Ng \& Gujar, 2009a\&b; Ng \& Tongzon, 2010; Hanaoka \& Regmi 2011; Beresford et al. 2012; Gangwar et al., 2012; Ng \& Cetin, 2012; Lu \& Chang 2013; Monios \& Wang, 2013), Africa (e.g. Garnwa et al., 2009; Kunaka, 2013) and Latin America (e.g. Padilha \& Ng, 2012; Ng et al., 2013) has begun to be published, it remains the case that a geographical understanding of the spatial development of intermodal freight transport in developing economies has been insufficiently developed ( $\mathrm{Ng} \&$ Cetin 2012; Notteboom \& Rodrigue 2009).

The hinterland freight geography of North America represents a landbridge and Europe is based on coastal gateways and inland load centres (Rodrigue \& Notteboom, 2010), while the East Asian hinterland model has been categorised as coastal concentration with low inland coverage (Lee et al. 2008). European and North American seaports are generally conceptualised as increasingly integrated with their hinterlands, as per the regionalisation model, but the historical lack of inland penetration of Asian and Latin American ports would suggest that such hinterland integration models do not apply there. While this appears to be true in India (Ng \& Cetin, 2012) and Latin America (Ng et al., 2013), in China this spatial pattern is being altered by, for example, the establishment of several inland ports in the 
Chinese hinterland over the last decade. Monios \& Wang (2013) found that the inland port network emerging in China reflects similarities to patterns observed in more integrated networks such as Europe and North America. Similarly, recent research indicates that the hinterland strategies of globalised port terminal operators in Central America exhibit some replication of European port-driven strategies also (Rodrigue \& Wilmsmeier, 2013).

Monios and Wilmsmeier (2012a) showed that inland terminals have experienced difficulties attracting port flows unless a port actor has been involved from the beginning, and hypothesised that inland terminals developed on the basis of intermodal flows with ports can only be successful if a close operational relationship, if not full integration, with the port terminal operator is established from the outset. The literature suggests that integration with ports is difficult and consequently rare, requiring a number of difficult obstacles to be overcome, which will become clearer in the following sections of this paper.

\subsection{Conclusion}

While the port regionalisation concept suggests that regionalisation is imposed on ports, the literature reveals that ports can actively develop inland terminals. Moreover, differences exist between those developed by port authorities and those developed by port terminal operators. In the cases extant in the literature, the most successful model appears to be the port terminal operator, perhaps because the port authority is rarely in a position to achieve such operational "extended gate" integration, thus limiting the potential for successful inland terminal developments by port authorities. This finding suggests that an enlarged institutional capacity may be an increasingly important source of competitive advantage in the port industry.

\section{The role of logistics and inland freight circulation in port regionalisation}

\subsection{Introduction}

Mentzer et al. (2004; p.607) described logistics management as "a within-firm function that has cross-function and cross-firm (i.e. boundary-spanning) aspects to it." Logistics decisions influence potential integration, such as trends in the last two decades for the centralisation and relocation of plants and distribution centres, a reduction in the supplier base and a consolidation of the carrier base (Lemoine \& Skjoett-Larsen, 2004; Abrahamsson \& Brege, 1997; O’Laughlin et al., 1993).

The relevant issues from the logistics literature can be grouped into two sections: concentration and centralisation of distribution strategies and processes of logistics 
integration. This literature will be described and discussed in order to determine how the key features of these processes can influence port regionalisation.

\subsection{Distribution: concentration and centralisation}

Hesse (2004) showed how the real estate market for logistics has changed from one with high ownership levels, primarily local firms, few speculative developments, 10 year leases and a weak investment market to a situation with an increasing share of rental sites, international developers, speculative development, shorter leases of 3-5 years and a strong investment market for new developments. Average warehouse size has been shown to be increasing in both the UK and the US (McKinnon, 2009; Cidell, 2010) as is the tendency to agglomeration, with companies locating their DCs within large logistics parks (McKinnon, 2009).

Such processes are difficult for port actors to control; therefore, when port regionalisation occurs it is, to an extent, "imposed on ports" by the actions of inland logistics actors. However, as noted by Notteboom (2010), the geographical concentration of inland logistics zones produces load centres and high density corridors served by inland terminals. This provides the opportunity for large port authorities to take a direct involvement, as seen in the previous section. However, inland logistics remains fragmented in many cases and different strategies are adopted based on regional characteristics.

For example, distribution strategies can be based on direct gateway distribution (Pettit \& Beresford, 2009; Wang \& Ducruet, 2012). Alternatively, distribution can be based on tiered systems of first (e.g. Europe-wide or east/west US) and second-tier (e.g. regional) distribution centres (Rodrigue \& Notteboom, 2010). Firms commonly utilise a mixture of gateway logistics for Far East imports, inland hubs for slow-moving domestically-sourced stock and local distribution centres for fast-moving products (Rodrigue \& Notteboom, 2009; 2010).

Monios (2012) looked in detail at the use of intermodal transport by large British retailers and found that, despite operational integration in some instances, the concentration of distribution centres in the centre of the country and the focus on domestically-sourced product created a separation between port and inland flows. The role of 3PLs was essential to consolidate flows to support intermodal corridors, but the operational issues of wagon and container imbalances, as well as the terminal handling costs, still threatened the feasibility of rail operators providing the service. The primary domestic corridor in the UK is the AngloScottish route, where domestic ambient product moves northbound in $45 \mathrm{ft}$ pallet-wide containers, backfilled with a combination of Scottish suppliers and other consolidated loads. 
The port flows are palletised or break bulk general merchandise in 20/40ft deepsea containers. These product and route characteristics affect rail efficiency because port flows are generally hauled by Freightliner on $60 \mathrm{ft}$ wagons to cater for $20 \mathrm{ft}$ and $40 \mathrm{ft}$ containers, while domestic flows are hauled by Direct Rail Services in conjunction with 3PLs in $45 \mathrm{ft}$ boxes on $54 \mathrm{ft}$ wagons.

One port regionalisation strategy adopted by ports to incorporate themselves into domestic logistics patterns is port-centric logistics, which has been discussed elsewhere in more detail (Mangan et al., 2008; Pettit \& Beresford, 2009; Monios \& Wilmsmeier, 2012b). It is being used in the UK as a way for regional ports to compete with mainports but it has limitations, such as backhaul and container type mismatches, and, more broadly, a difficulty in overcoming centralised inventory strategies. Another downside is that the company is anchored at that port with little option if a shipping line raises its prices or moves to another port, whereas intermediate locations in the centre of the country allow the shipper to take advantage of competitive rates from several ports and shipping lines. This finding underlines the reluctance of inland actors to integrate with maritime actors.

\subsection{Logistics integration}

In supply chain management, vertical collaboration involves relationships with supply chain partners up and down the chain. In vertical logistics collaboration, the integration is not along the supply chain but relates to the provision of logistical services, including transport. Examples of vertical collaboration in transport and logistics include vendor managed inventory (VMI), efficient consumer response (ECR) and collaborative planning, forecasting and replenishment (CPFR) (McCarthy \& Golicic, 2002; Esper \& Williams, 2003; SkjoettLarsen et al., 2003; Tuominen, 2004; Cruijssen et al., 2007). A shipper forming a relationship with a 3PL and a rail operator would be an example of vertical collaboration as far as intermodal logistics is concerned (Lehtinen \&Bask, 2012).

As with horizontal supply chain collaboration, horizontal collaborations in logistics are likewise with competitors; for example, 3PLs or transport providers running services together, or shippers combining loads together to provide economies of scale. A further complication is when a 3PL combines loads for separate customers, which is not actual horizontal collaboration on behalf of the shippers but achieves a similar effect. It could even be described as a horizontal cooperation with a vertical character, for example when a number of shippers adopt similar pallet or container types or use a shared transport hub in order for a 3PL or transport provider to provide a joint service with lower cost to all users. 
Mason et al. (2007; p.188) discussed the need to combine "vertical collaboration to reduce costs and improve service levels as well as horizontally with industry partners to better utilise assets and hence to further reduce costs." Cruijssen et al. (2007) noted that horizontal collaboration is common in the maritime and aviation sectors, but less so in landside transport and logistics, due to different characteristics, such as the large number of players and increasing competitiveness and its less capital-intensive nature.

Bowersox et al. (1989) established a 5-stage model of logistics integration, from single to repeated transactions, then partnerships, followed by third-party agreements and finally integrated service agreements. Successful logistics integration requires high levels of cooperation such as synchronising the logistics decision horizon for forward-looking planning, consolidating multi-party logistics processes such as matching shippers and carriers or resource availability, and integrating functional scope such as product development, logistics and marketing (Simatupang \& Sridharan, 2002). As with the key features of distribution patterns examined in section 5.2, these features of inland logistics cooperation also reveal why inland transport is not integrated horizontally and vertically in the way that maritime transport has become.

Logistics integration in the supply chain has been a recurring theme in the maritime transport literature (e.g. Heaver et al., 2000; Heaver et al., 2001;Frémont, 2009; Olivier \& Slack, 2006; Van de Voorde \& Vanelslander, 2009), partly due to the high proportion of door-to-door costs represented by the inland leg (Graham, 1998; Notteboom \& Winkelmans, 2001; Notteboom and Rodrigue, 2005). Graham (1998) wrote that "the land-side is characterized by relatively low investment, high operating expenses, little scale incentive to collective operation and a considerable level of unremunerated activity requiring cross payment out of sea freight" (p.135); fifteen years later, this statement remains true and explains both why port actors want to control hinterland links, and why it remains so difficult.

In the past decade, shipping lines and port terminal operators have consolidated and integrated their portfolios through mergers and acquisitions, resulting in a small number of dominant firms. These firms have since benefited from significant economies of scale and scope and enabled them to provide something of a seamless intermodal transport movement from port to port. There is as yet insufficient evidence that this trend has occurred inland, and the characteristics of inland logistics as just described through literature review reveal that it will not be likely in the majority of instances. For true intermodality to be successful and 
economically feasible, land transport operations require a similar level of consolidation to that of the sea leg.

There will, nevertheless, be some efforts by ports especially on big ticket projects like the Alameda Corridor (see next section). But these remain in the minority and are the province of large ports only, considering the money, time and institutional difficulty and adaptation required (again, see next section).

\subsection{Conclusion}

Large shippers are seeking greater control of their distribution in some ways, but they tend to work in partnership with 3PLs rather than integrating with them in the way that 3PLs have integrated to some degree with road haulage. Likewise, 3PLs work closely with rail operators but are not integrated with them. A series of complex relationships persists in the industry, suggesting that the dominant players in the market for inland freight circulation are not integrating or even cooperating to the extent that shipping lines are for maritime flows. Reluctance for such integration or even collaboration is a barrier to consolidation, which is necessary for greater use of intermodal transport and prevents intermodal corridors becoming instruments of hinterland capture and control for most ports. Port regionalisation cannot take place effectively while inland and maritime logistics systems remain separated by such operational issues, and little incentive has been identified for any user to solve this collective action problem, which is a topic that will now be addressed.

\section{The role of collective action problems in port regionalisation}

\subsection{Introduction}

Research has shown how spatial development is to a large degree an institutional problem, as intermodal corridors involve many actors that are integrated at different levels and managed by varying arrangements. These issues can be grouped into two sections: the collection action problem requiring coordination mechanisms and the institutional adaptations of port actors.

\subsection{Reason for collective action problems and the need for coordination mechanisms}

Van der Horst and de Langen (2008) highlighted five reasons why coordination problems exist: unequal distribution of costs and benefits (free rider problem), lack of resources or willingness to invest, strategic considerations, lack of a dominant firm, risk-averse behaviour/short-term focus. A variety of coordination mechanisms have arisen to manage this process, such as vertical integration, partnerships, collective action and changing the incentive structure of contracts (de Langen \& Chouly, 2004; de Langen \& Visser, 2005; Van 
der Horst and De Langen, 2008; Van der Horst \& Van der Lugt, 2011), but regional differences can be observed; for example, Ducruet and Van der Horst (2009) found differences in port-hinterland transport integration between northern and southern European container ports. The "hinterland access regime" proposed by De Langen and Chouly (2004; p. 362) views the collaborative activities undertaken by a number of actors as a governance issue because "even though collective action is in the interest of all the firms in the port cluster, it does not arise spontaneously".

Much of this research has made use of theory from institutional economics (e.g. Coase, 1937; Williamson, 1975, 1985; North, 1990; Aoki, 2007) to analyse cooperative behaviour in intermodal transport corridors, a full analysis of which is beyond the scope of this paper. Monios and Lambert (2013) analysed a collective action problem in an intermodal corridor development in the United States and found a conflict between legitimacy and agency and a limitation of political organisations due to their design, both of which were expected from the institutional literature (e.g. Meyer and Rowan, 1977; Moe, 1990). These issues account for the high incidence of policy churn, lack of agency and sometimes lack of communication between the public and private sectors. The role of informal networking was also found to be important as it can overcome institutional inertia, although it is difficult to capture this process, and harder still to attempt to institute it in another setting through policy action. As institutional capacity is scaled at the state level in the United States, lessons can be learned for the multi-scaled EU transport planning regime, such as the importance of informal regional cohesion across devolved governance spaces.

Rodrigue (2004) demonstrated how intermodal freight corridors represent the regional scale of freight distribution, linking the local and global levels. Thus the globalised distribution channels underpinning the physical separation of freight production, manufacture and consumption connect local zones of production and consumption through regional corridors. Yet, while the corridor focus is attractive as a planning concept,as international corridors cross national and regional boundaries, they do not always fit comfortably into national spatial plans and at regional and local levels there is fear of "ribbon development" (Priemus \& Zonneveld, 2003) and uneven economic development that simultaneously benefits some areas while depleting others (Chapman et al., 2003).Lehtinen and Bask (2012) showed the difference the correct business model can make.

Branding of a corridor (e.g. the Heartland Corridor - see Monios \& Lambert, 2013) or establishing a specified institutional structure and governance regime can be important elements of corridor success, whether for attracting funding, resolving operational problems 
or harmonising regulations at border crossings (Kunaka, 2013). Such institutional initiatives have been tried in Africa for long distance corridors crossing several countries, some of which are land locked and have a significant interest in developing efficient transport corridors for access to neighbouring ports (Adzigbey et al. 2007). The port's role in such initiatives is limited.

Flämig and Hesse (2011)identified a conflict between legitimacy and efficiency of state actors in managing the planning conflicts arising from the collective action problem represented by port regionalisation. The authors concluded that three issues needed to be addressed: the interdependence of logistics and land use, the regional setting of the port and its functions, and the role of governance and planning. Monios \&Wilmsmeier (2012a; p.1560) wrote that "the emerging stage in port development theory must understand relations between port authorities, port terminal operators, inland terminal operators (including the transport link between the two) and logistics providers." Building on the previous two sections, this finding highlights the importance of establishing port involvement from the beginning and the need to understand logistics integration if the collective action problem of developing intermodal corridors is to be resolved and managed to the port's advantage.

Flämig and Hesse (2011)further identified a lack of institutional capacity to deal with unexpected developments and logistics sprawl, conflicting with public sector attempts to coordinate new freight transport requirements around intermodal corridors and terminals. Insights from economic and political geography have also proved useful in this endeavour, comparing how these structures differ across scales and spaces (MacLeod, 2001), as well as problematizing the role of the state (e.g. Swyngedouw, 2000; Jessop, 1990; Brenner, 1998), and reflecting multi-level governance (Marks, 1993; Hooghe \& Marks, 2003). This process is linked partly to recent trends towards decentralisation and devolution (Peck, 2001; Rodríguez-Pose \& Gill, 2003), which nonetheless are not necessarily an actual transfer of power but more of a qualitative restructuring (Brenner, 2004), characterised as uneven processes of hollowing out (Rhodes, 1994) and filling in (Jones et al., 2004; Goodwin et al., 2005), leading to asymmetrical acting capacity.

\subsection{Institutional adaptations of port actors}

The changing role of the port in the transport chain and the greater focus on the terminal rather than the port have become key issues over recent years (e.g. Slack, 1999; Notteboom \& Winkelmans, 2001; Robinson, 2002; Slack \& Wang, 2002; Slack, 2007), leaving the role of the port authority open to question (Heaver et al., 2000; Olivier and Slack, 2006; Notteboom 
\& Rodrigue, 2009). From a theoretical perspective, this changing role has been addressed through relational (Jacobs \& Notteboom, 2011), territorial (Debrie et al., 2013) and combined approaches (Monios \& Wilmsmeier, 2012b).

As shown in the first part of the analysis, land-driven terminal developments have generally been the most common as port actors have not possessed the institutional capacity to drive developments deep in the hinterland, but this situation is changing as port congestion and fierce competition for overlapping hinterlands force port authorities and terminal operators to take investments and even drive such developments themselves (Monios \& Wilmsmeier, 2012a; Monios \& Wang, 2013). In order to achieve this, port actors are required to expand their institutional capacity beyond their core competency of container handling and restructure their business models through, for example, processes of privatisation or corporatisation (Notteboom \& Rodrigue, 2005; Ng \& Pallis, 2010; Sanchez \& Wilmsmeier, 2010; Jacobs \& Notteboom, 2011; Notteboom et al., 2013).

Institutional approaches to port development have argued that the port authority has constraints on its ability to act, stemming from its specific nature. The key distinction is that port development is path dependent, heavily constrained by past actions and institutional design, but also contingent, in relation to private investment and public planning. $\mathrm{Ng}$ and Pallis (2010) showed how port governance is largely determined by local/regional institutional characteristics, despite attempts to implement generic governance solutions. Notteboom et al. (2013) applied the concept of institutional plasticity (Strambach, 2010) to port development, arguing that, while port development is path dependent, a port authority can achieve governance reform by a process of adding layers to existing arrangements. In this way, the port authority does not break from the existing path of development, but develops new capabilities and activities via a process of "institutional stretching". An example is given of port authorities investing in load centres in the hinterland, beyond their traditional jurisdiction, and the particular importance of informal networking is noted. Jacobs \& Notteboom (2011) asserted the need for an evolutionary perspective, drawing upon the economic geography literature to define the movement from critical moments to critical junctures, concluding that port authorities have "windows of opportunity" in which collective action is possible. The authors concluded that "the question of to what extent critical moments require institutional adaptations in order to materialise into critical junctures needs further thought" (p.1690).

Wilmsmeier et al. (2013) explored some factors that turn critical moments into critical junctures through an analysis of secondary port development in Latin America and the 
Caribbean. This theoretical endeavour was aided through the application of the concept of autopoiesis (Maturana \& Varela, 1980), introduced to port geography by Sanchez and Wilmsmeier (2010), who observed that transport systems exhibit an autopoietic selforganising structure. Under pressure from an uncertain environment, a transport system takes actions in order to tackle existential situations (otherwise market forces will deconstruct the organisation of the transport system). When feedback loops are missing, parts of the system may grow in an uncontrollable manner, and, through the limitations of its physical characteristics, it may lead to overshooting and collapse of the system. Yet with each transformation of the inputs, the system changes its state (Schober, 1991, p.3520).

This characterisation of ports could provide an avenue for future research, aiming to determine how institutional adaptations proceed, influenced both by globalised norms (e.g. strategy reproductions by global terminal operators) and regional specificities. The "lumpiness" of investment in both port and intermodal infrastructure means that institutional asymmetries can produce divergent trajectories (Ng \& Pallis, 2010). Transport autopoiesis is likely to have an especially high inertia when it comes to changing system variables (see Maturana, 1994, p.77; Jantsch, 1982, p.64). More research is needed to investigate the influence of these system variables, which, like the factors influencing deconcentration of maritime flows (see Ducruet et al., 2009; Notteboom, 2010; Wilmsmeier \& Monios, 2013), will be a mixture of reactive and proactive. In order to theorise port regionalisation fully, such factors require deeper understanding.

\subsection{Conclusion}

Collective action problems arise from the difficulties in managing the actors involved in hinterland integration. The literature reveals how the planning and operation of intermodal corridors require multi-scaled governance and informal regional coherence that port actors are not generally in a position to influence. The findings from this section highlight the importance of identifying at which level transport governance is scaled, and how public and private organisations interact within and across these scales.

Large shippers or rail operators competing against each other do not always favour the integration required for successful port regionalisation, as shown in section 5. Even leader firms can be reluctant to act if an infrastructure for collective action is not in place (and it is usually predominantly a public infrastructure for collective action), which hampers attempts at port regionalisation and keeps maritime and inland spaces separate. However, port actors have pursued institutional adaptations in order to take an active role in hinterland 
investments. In order for the port regionalisation concept to theorise hinterland expansion adequately, further research is needed on the influences and constraints on proactive and reactive strategies. The institutional theoretical approaches discussed in this section are likely to be instrumental in this endeavour.

\section{Discussion of results}

Each of the three parts of the analysis highlighted conflicts between maritime and inland actors, a lack of integration, institutional barriers, and the importance of understanding the specificity of market structure and the limitations of political design, both of which limit the extent to which port regionalisation processes can occur. However, these issues remain context-dependent, thus challenging the ability to capture them in a single concept.

As Rodrigue et al. (2010) noted about inland terminals, "the inland port is only an option for inland freight distribution that is more suitable as long as a set of favourable commercial conditions are maintained" (p.2). Similarly, it might be said that port regionalisation requires a set of favourable commercial and institutional conditions to be maintained. The findings from the literature analysed in this paper suggest that it is not easy to maintain such conditions.

Port devolution and the deregulation of transport services have opened wider possibilities for the private sector, public sector and varying forms of cooperation between the two. Land use and transport planning require integrated approaches across local, regional and national boundaries to be able proactively to influence and direct port development. As with the discussion on terminal development in section 4 , the operational discussion in section 5 highlighted the difficulty of making intermodal transport feasible, especially in Europe. Many terminals had their development subsidised by the public sector, and many operators still receive public funds. Moreover, as many rail operators in Europe continue to receive subsidies from their national governments, this subsidy indirectly supports the small terminals that continue to exist.

Local and regional planning authorities, as well as national bodies who tend to provide the funding, must improve the integration of their transport planning with industry needs, whether that be market demand or operational requirements. Section 6 highlighted the difficulties of managing such institutional relationships across spaces and scales. In particular, the importance of informal regional cohesion across devolved governance spaces was demonstrated, a finding of particular relevance to the European context, where subsidies can be local, regional, national or supranational (i.e. the European Union). 
Port actors do not generally have the institutional capacity to drive developments far beyond their perimeter. This is particularly the case for port authorities (generally working on a public mandate from the city or region), but even private port terminal operators are generally working to a core competency and the institutional structure (as represented by the board of directors who report to the shareholders) is unlikely to be suited to the requirements relating to purchasing land and dealing with the regulatory and other issues of developing a subsidiary in the hinterland. Short-range satellite terminals for overspill functions can be feasible (Slack, 1999), but load centres hundreds of miles away are not generally compatible with the aims of the port. However, the literature has shown that some port terminal operators have successfully invested in hinterland terminals. The port regionalisation concept focuses primarily on the port authority and the literature on institutional adaptations showed that port authorities are taking a more direct role in hinterland access. Yet the real investments and actions in the hinterland are being taken by port terminal operators. Therefore, the port regionalisation model as it currently stands devotes insufficient attention to the role of the port terminal operator, which, as noted by Slack and Wang (2002), must be considered an essential part of any new spatial model of port geography.

Wilmsmeier et al. $(2010,2011)$ borrowed from the terminology of industrial organisation (i.e. forward and backward integration) to introduce a conceptual approach to inland terminal development, contrasting Inside-Out development (land-driven e.g. rail operators or public organisations) with Outside-In development (sea-driven e.g. port authorities, terminal operators). The authors argued that this perspective had not received sufficient attention in discussions of the port regionalisation concept. This model has since been used to aid disaggregation of regionalisation strategies and comparison of potentially conflicting strategies that may be pursued by terminals within a port or between ports within the same range. $\mathrm{Ng} \&$ Cetin (2012) suggested that Inside-Out development is the common model in developing countries, as opposed to Outside-In in developed countries, whereas Monios \& Wilmsmeier (2012a) showed that Inside-Out development is common in developed countries also. Increasing port competition in China has spurred several Outside-In developments there (Monios \& Wang, 2013).

The literature analysis revealed the lack of integration and the limitations of the port to act, elucidating good reasons why ports may experience challenges in controlling or capturing hinterlands through the strategies of integration that the port regionalisation concept suggests. Therefore, while the concept is correct to some degree to state that regionalisation is "imposed on ports" (p.302) by landside actors, and that "the port itself is 
not the chief motivator for and instigator of regionalisation" (p.306), an inherent contradiction is revealed because the concept also asserts the importance of port competition and the requirement for port actors to capture and control these emerging inland networks, for example by developing an "island formation" in "the natural hinterland of competing ports" (p.303). In highlighting the limitations of the port actors to do so, this paper has deepened understanding of the difficulties of port regionalisation. It particularly highlights reasons why it will mostly be large ports with the necessary resources that are likely to engage in such tactics, meaning that the levels of integration required for a true regionalisation process worthy of the name will be the exception rather than the norm.

The port regionalisation concept therefore requires adjustment to highlight the opportunities for and barriers to successful port regionalisation, and recognise inherent difficulties.

\section{Conclusion}

According to the port regionalisation concept, inland terminals are active nodes, inland logistics integration is driven by market players and collective action problems can challenge the port's ability to act. This paper has examined the literature on these topics in order to identify challenges to the processes of integration essential to the concept. This understanding facilitates both the improvement of the model as well as the identification of lessons for port actors regarding how to achieve successful port regionalisation, or to cope with such processes as they are played out by other actors.

The analysis in this paper identified several difficulties arising from the nature of intermodal transport that may challenge successful implementation of port regionalisation strategies. Section 4 showed that ports can actively develop inland terminals, and differences exist between those developed by port authorities and those developed by port terminal operators. Furthermore, differences can be observed between those developed by ports and those developed by inland actors. Section 5 revealed that while rail remains a marginal business, while the industry remains fragmented, while consolidation is not happening and while fragile government subsidy is still the basis of many flows, intermodal corridors cannot become instruments of hinterland capture and control for ports. The integration processes predicted by the port regionalisation concept cannot happen until the inland logistics system becomes more integrated. There is insufficient evidence as yet that inland transport is consolidated to the extent that maritime transport (e.g. global shipping lines and terminal operators) has become over recent years. Section 6 found that in many cases institutional 
design will constrain integration between maritime and inland transport systems. The conflict between legitimacy and agency creates barriers and if an infrastructure for collective action is not in place (and it is usually predominately a public infrastructure for collective action), then private firms will not act, thus challenging attempts at port regionalisation and keeping the maritime and inland spaces separate. The multi-scalar formal and informal planning regimes in which each port is situated mean that generic port development strategies based on assumptions of hinterland integration will face several regionally-specific challenges. Some institutional adaptation has been identified on behalf of port authorities, but port terminal operators remain the most likely port actors to engage in active regionalisation strategies.

While additional cases are required to advance the findings further, the cases in this paper elucidate reasons that may prevent ports controlling or capturing hinterlands through the strategies of integration that the port regionalisation concept suggests. The paper also argues for greater disaggregation of the factors that challenge or enable port regionalisation processes, comparing the institutional models of ports and other stakeholders, particularly public sector planners and funders. It may be more accurate to state that port regionalisation can only occur as long as a set of favourable commercial and institutional conditions are maintained.

While the findings from the cases presented in this paper suggest that it is not easy to maintain such conditions, some examples of best practice have shown that they can be altered. For instance, the commercial conditions can be altered (e.g. port terminals taking a direct role in managing hinterland rail services), as can the institutional conditions (e.g. institutional adaptation to allow port authorities to take direct investments in the hinterland).This best practice has been isolated through a better understanding of the different elements of intermodal transport as outlined in this paper.

From a theoretical perspective, recent work on institutional adaptation at ports suggests that port regionalisation, "imposed on ports", has caused them to change their institutional design and their relation to their own core competencies. Processes of "institutional plasticity", "windows of opportunity" and "autopoiesis" have been identified, pointing towards a future research agenda examining how the competitive strategies adopted by port authorities and terminal operators fit with the local and regional economic development goals of landside actors.

\section{Acknowledgments}

Removed for blind review 


\section{References}

Abrahamsson, M., Brege, S., 1997. Structural changes in the supply chain. International Journal of Logistics Management, 8 (1), 35-44.

Adzigbey, Y., Kunaka, C., \& Mitiku, T. N., 2007. Institutional Arrangements for Transport Corridor Management in Sub-Saharan Africa. SSATP working paper 86. Washington DC: World Bank.

Aoki, M., 2007. Endogenizing institutions and institutional changes. Journal of Institutional Economics. 3(1), 1-31.

Barke, M., 1986.Transport and Trade; conceptual frameworks in geography,Edinburgh: Oliver \& Boyd.

Beresford, A. K. C., Gardner, B. M., Pettit, S. J., Naniopoulos, A., Wooldridge, C. F., 2004. The UNCTAD and WORKPORT models of port development: evolution or revolution? Maritime Policy \& Management, 31, 93-107.

Beresford, A., Pettit, S., Xu, Q., Williams, S., 2012. A study of dry port development in China. Maritime Economics \& Logistics. 14 (1), 73-98.

Bergqvist, R., Falkemark, G., Woxenius, J., 2010. Establishing intermodal terminals. World Review of Intermodal Transportation Research. 3 (3), 285-302.

Bichou, K., Gray, R., 2005. A critical review of conventional terminology for classifying seaports. Transportation Research Part A: Policy and Practice, 39, 75-92.

Bird, J., 1963.The Major Seaports of the United Kingdom,London: Hutchinson \& Co.

Bowen, J., 2008. Moving places: the geography of warehousing in the US. Journal of Transport Geography. 16 (6),379-387.

Bowersox, D.J., Daugherty, P.J., Dröge, C. L., Rogers, D. S., Wardlow, D.L., 1989. Leading edge logistics:competitive positioning for the 1990s, Oak Brool, IL: Council of Logistics Management.

Brenner, N., 1998. Between fixity and motion: accumulation, territorial organization and the historical geography of spatial scales. Environment \& Planning D. 16 (5), 459-481.

Brenner, N., 2004.New State Spaces; Urban Governance and the Rescaling of Statehood,Oxford: Oxford UP.

Chapman, D., Pratt, D., Larkham, P., Dickins, I., 2003. Concepts and definitions of corridors: evidence from England's Midlands. Journal of Transport Geography. 11 (3), 179-191.

Cidell, J., 2010. Concentration and decentralization: the new geography of freight distribution in US metropolitan areas. Journal of Transport Geography. 18 (3), 363-371. 
Coase, R. H., 1937. The nature of the firm. Economica 4(16), 386-405.

Choong, S. T., Cole, M. H., Kutanoglu, E., 2002. Empty container management for intermodal transportation networks. Transportation Research Part E: Logistics and Transportation Review. 38 (6), 423-438.

Cruijssen, F., Dullaert, W., Fleuren, H., 2007. Horizontal cooperation in transport and logistics: a literature review. Transportation Journal. 46 (3), 22-39.

Dablanc, L., Ross, C., 2012. Atlanta: a mega logistics center in the Piedmont Atlantic Megaregion (PAM). Journal of Transport Geography. 24, 432-442.

Debrie, J., Lavaud-Letilleul, V., Parola, F., 2013. Shaping port governance: the territorial trajectories of reform. Journal of Transport Geography. 27, 56-65.

De Langen, P. W., Chouly, A., 2004. Hinterland access regimes in seaports. European Journal of Transport and Infrastructure Research. 4 (4), 361-80.

De Langen, P., Visser, E-J., 2005. Collective action regimes in seaport clusters: the case of the Lower Mississippi port cluster. Journal of Transport Geography. 13 (2), 173-186.

Ducruet, C., 2009. Port regions and globalization. In: T Notteboom, C. Ducruet, P. deLangen (Eds.),Ports in Proximity, Farnham: Ashgate.

Ducruet, C., Roussin, S., Jo, J-C. 2009. Going west? Spatial polarization of the North Korean port system. Journal of Transport Geography. 17 (5), 357-368.

Ducruet, C., Van der Horst, M. 2009. Transport integration at European ports: measuring the role and position of intermediaries. EJTIR. 9 (2), 121-142.

Esper, T. L., Williams, L. R., 2003. The value of collaborative transportation management (CTM): its relationship to CPFR and information technology. Transportation Journal. 42 (4), 55-65.

Flämig, H., Hesse, M., 2011. Placing dryports. Port regionalization as a planning challenge the case of Hamburg, Germany, and the Süderelbe. Research in Transportation Economics. 33 (1), 42-50.

Frémont, A., 2009. Empirical evidence for integration and disintegration of maritime shipping, port and logistics activities. JTRC OECD/ITF Discussion Paper 2009-1.

Gangwar, R., Morris, S., Pandey, A., Raghuram, G., 2012. Container movement by rail in India: a review of policy evolution. Transport Policy. 22 (1), 20-28

Garnwa, P., Beresford, A, Pettit, S., 2009. Dry ports: A comparative study of the UK \& Nigeria. In: UNESCAP. Transport and Communications Bulletin for Asia and the Pacific. No. 78: Development of Dry Ports. New York: United Nations. 
Goodwin, M., Jones, M., Jones, R. 2005. Devolution, constitutional change and economic development: explaining and understanding the new institutional geographies of the British state. Regional Studies. 39 (4), 421-436.

Gouvernal, E., Debrie, J., Slack, B., 2005. Dynamics of change in the port system of the western Mediterranean. Maritime Policy \& Management. 32 (2), 107-121.

Graham, M. G., 1998. Stability and competition in intermodal container shipping: finding a balance. Maritime Policy \& Management. 25 (2), 129-147.

Groothedde, B., Ruijgrok, C. \& Tavasszy, L., 2005. Towards collaborative, intermodal hub networks: A case study in the fast moving consumer goods market. Transportation Research Part E: Logistics and Transportation Review. 41 (6), 567-583.

Hanaoka, S., Regmi, M. B., 2011. Promoting intermodal freight transport through the development of dry ports in Asia: an environmental perspective. IATSS Research. 35 (1), $16-23$.

Hayuth, Y., 1981. Containerization and the load center concept. Economic Geography, 57, 160-176.

Heaver, T., Meersman, H., Moglia, F., Van de Voorde, E., 2000. Do mergers and alliances influence European shipping and port competition? Maritime Policy \& Management, 27, 363-373.

Heaver, T., Meersman, H., Van de Voorde, E., 2001. Co-operation and competition in international container transport: strategies for ports. Maritime Policy \& Management, 28, 293-305.

Hesse, M., 2004. Land for Logistics: locational dynamics, real estate markets and political regulation of regional distribution complexes. Tijdschrift voor Sociale en Economische Geografie. 95 (2), 162-173.

Höltgen, D., 1996. Intermodal Terminals in the Trans-European Network. Discussion Paper, European Centre for Infrastructure Studies, Rotterdam.

Hooghe, L. \& Marks, G., 2001. Multi-Level Governance and European Integration, Boulder: Rowman \& Littlefield.

Hoyle, B. S., 1968. East African seaports: an application of the concept of 'anyport'. Transactions \& Papers of the Institute of British Geographers, 44, 163-183.

Jacobs, W., 2007. Port competition between Los Angeles and Long Beach: an institutional analysis. Tijdschrift voor Economische en Sociale Geografie, 98, 360-372. 
Jacobs, W., Notteboom, T., 2011. An evolutionary perspective on regional port systems: the role of windows of opportunity in shaping seaport competition. Environment \& Planning A. 43 (7), 1674-1692.

Jantsch, E., 1982. Selbstorganisation des Universums, Munich, Germany.

Jessop. B., 1990. State Theory: Putting Capitalist States in their Place, Cambridge: Polity.

Jones, R., Goodwin, M., Jones, M., Simpson, G., 2004. Devolution, state personnel and the production of new territories of governance in the United Kingdom. Environment \& Planning A. 36 (1), 89-109.

Konings, R., 2007. Opportunities to improve container barge handling in the port of Rotterdam from a transport network perspective. Journal of Transport Geography. 15 (6), 443-454.

Konings, R., Kreutzberger, E., Maraš, V., 2013. Major considerations in developing a huband-spoke network to improve the cost performance of container barge transport in the hinterland: the case of the port of Rotterdam. Journal of Transport Geography. 29, 6373.

Kunaka, C., 2013. Dry ports and trade logistics in Africa. In: R. Bergqvist, K. P. B. Cullinane, G. Wilmsmeier (Eds.), Dry ports: a global perspective, London: Ashgate.

Lee, S-W., Song, D-W., \& Ducruet, C., 2008. A tale of Asia's world ports: the spatial evolution in global hub port cities. Geoforum, 39(1), 372-385.

Lehtinan, J., Bask, A. H., 2012. Analysis of business models for potential 3Mode transport corridor. Journal of Transport Geography. 22 (1), 96-108.

Lemoine, O. W., Skjoett-Larsen., 2004. Reconfigurations of supply chains and implications for transport; a Danish study. International Journal of Physical Distribution and Logistics Management. 34 (10), 793-810.

Liedtke, G., Carillo Murillo, D. G., 2012. Assessment of policy strategies to develop intermodal services: the case of inland terminals in Germany. Transport Policy 24, 168178.

Lovering, J., 1999. Theory led by policy: the inadequacies of the 'new regionalism' (illustrated from the case of Wales). International Journal of Urban and Regional Research. 23 (2), 379-395.

Lu, J., \& Chang, Z., 2013. The construction of seamless supply chain network - development of "dry ports" in China. In: R. Bergqvist, K. P. B. Cullinane, G. Wilmsmeier (Eds.), Dry ports: a global perspective,London: Ashgate. 
MacLeod, G., 2001. Beyond soft institutionalism: accumulation, regulation and their geographical fixes. Environment \& Planning A,33(7), 1145-1167.

Mangan, J., Lalwani, C., Fynes, B., 2008. Port-centric logistics. The International Journal of Logistics Management. 19 (1), 29-41.

Marks, G., 1993. Structural Policy and Multilevel Governance in the EC. In:A. Cafruny, G. Rosenthal (Eds.), The State of the European Community, Boulder: Lynne Rienner, pp. 391-411.

Martí-Henneberg, J., 2013. European integration and national models for railway networks (1840-2010). Journal of Transport Geography. 26, 126-138.

Mason, R., Lalwani, C., Boughton, R., 2007. Combining vertical and horizontal collaboration for transport optimisation. Supply Chain Management: An International Journal. 12 (3), 187-199.

Maturana, H. R., 1994. Was ist Erkennen? Munich, Germany

Maturana, H. R., Varela, F. J., 1980. Autopoiesis and Cognition, Dordrecht, Holland: D. Reidel.

McCarthy, T. M., Golicic, S. L., 2002. Implementing collaborative forecasting to improve supply chain performance. International Journal of Physical Distribution and Logistics Management. 32 (6), 431-454.

McKinnon, A., 2009. The present and future land requirements of logistical activities. Land Use Policy. 26S, S293-S301.

Mentzner, J. T., Min, S., Bobbitt, L. M., 2004. Toward a unified theory of logistics. International Journal of Physical Distribution and Logistics Management. 34 (8), 606627.

Meyer, J. W., Rowan, B., 1977. Institutionalized organizations: formal structure as myth and ceremony. American Journal of Sociology 83(2), 340-363.

Moe, T. M., 1990. Political institutions: the neglected side of the story. Journal of Law, Economics and Organization 6(special issue), 213-253.

Monios, J., 2011. The role of inland terminal development in the hinterland access strategies of Spanish ports. Research in Transportation Economics, 33, 59-66.

Monios, J., 2012. Retail logistics in the UK. International Conference on Logistics \& Sustainable Transport, Celje, Slovenia, June 2012.

Monios, J., 2014. Intermodal transport as a regional development strategy: the case of Italian freight villages. Growth and Change. In press. 
Monios, J., Lambert, B., 2013. The heartland intermodal corridor: public-private partnerships and the transformation of institutional settings. Journal of Transport Geography. 27 (1), $36-45$.

Monios, J., Wang, Y., 2013. Spatial and institutional characteristics of inland port development in China. GeoJournal. In press.

Monios, J., Wilmsmeier, G., 2012a. Giving a direction to port regionalisation. Transportation Research Part A: Policy \& Practice. 46 (10), 1551-1561.

Monios, J., Wilmsmeier, G., 2012b. Port-centric logistics, dry ports and offshore logistics hubs: strategies to overcome double peripherality? Maritime Policy and Management. 39 (2), 207-226.

Ng, K. Y. A., Cetin, I. B., 2012. Locational characteristics of dry ports in developing economies: some lessons from Northern India. Regional Studies. 46 (6), 757-773.

Ng, K. Y. A., Gujar, G. C., 2009a. Government policies, efficiency and competitiveness: the case of dry ports in India. Transport Policy. 16 (5), 232-239.

Ng, K. Y. A., Gujar, G. C., 2009b. The spatial characteristics of inland transport hubs: evidences from Southern India. Journal of Transport Geography. 17 (5), 346-356.

Ng, A. K. Y., Padilha, F., Pallis, A. A., 2013. Institutions, bureaucratic and logistical roles of dry ports : the Brazlian experience. Journal of Transport Geography. 27 (1), 46-55.

Ng, A. K. Y., Pallis, A. A., 2010. Port governance reforms in diversified institutional frameworks: generic solutions, implementation asymmetries. Environment \& Planning A 42(9), 2147-2167.

Ng, A. K. Y, Tongzon, J. L., 2010. The transportation sector of India's economy: dry ports as catalysts for regional development. Eurasian Geography \& Economics. 51 (5), 1-14.

North, D. C., 1990. Institutions, Institutional Change and Economic Performance, Cambridge: Cambridge University Press.

Notteboom, T. E., 2010. Concentration and the formation of multi-port gateway regions in the European container port system: an update. Journal of Transport Geography. 18 (4), $567-583$.

Notteboom, T., de Langen, P., Jacobs, W., 2013. Institutional plasticity and path dependence in seaports: interactions between institutions, port governance reforms and port authority routines. Journal of Transport Geography. 27, 26-35.

Notteboom, T. E., Rodrigue, J., 2005. Port regionalization: towards a new phase in port development. Maritime Policy \&Management, 32, 297-313. 
Notteboom, T. E., Rodrigue, J-P., 2009. Inland terminals within North American \& European Supply Chains. In: UNTAD,Transport and Communications Bulletin for Asia and the Pacific No. 78: Development of Dry Ports. New York: UNESCAP.

Notteboom, T. E., Winklemans, W., 2001. Structural changes in logistics: how will port authorities face the challenge? Maritime Policy \& Management, 28, 71-89.

O’Laughlin, K. A., Cooper, J C., Cabocal, E., 1993. Reconfiguring European Logistics Systems, Oak Brook: CLM.

Olivier, D., Slack, B., 2006. Rethinking the port. Environment \& Planning A, 38, 1409-1427.

Padilha, F., Ng, A. K. Y., 2012. The spatial evolution of dry ports in developing economies: the Brazilian experience. Maritime Economics \& Logistics. 14 (1), 99-121.

Peck, J., 2001. Neoliberalizing states: thin policies/ hard outcomes. Progress in Human Geography. 25 (3), 445-455.

Pettit, S. J., Beresford, A. K. C., 2009. Port development: from gateways to logistics hubs. Maritime Policy \& Management. 36 (3), 253-267.

Priemus, H., Zonneveld, W., 2003. What are corridors and what are the issues? Introduction to special issue: the governance of corridors. Journal of Transport Geography. 11 (3), 167-177.

Proost, S., Dunkerley, F., De Borger, B., Gühneman, A., Koskenoja, P., Mackie, P., Van der Loo, S., 2011. When are subsidies to trans-European network projects justified? Transportation Research Part A, 45, 161-170.

Rahimi, M., Asef-Vaziri, A., Harrison, R., 2008. An inland-port location-allocation model for a regional intermodal goods movement system. Maritime Economics \& Logistics. 10 (4), 362-379.

Rhodes, R.A.W., 1994. The Hollowing out of the State: The Changing Nature of the Public Service in Britain.The Political Quarterly, 65 (2), 138-51.

Rimmer, P. J., 1967. The search for spatial regularities in the development of Australian seaports 1861 - 1961/2. Geograkiska Annaler, 49, 42-54.

Robinson, R., 2002. Ports as elements in value-driven chain systems: the new paradigm. Maritime Policy \& Management, 29, 241-255.

Rodrigue, J-P., 2004. Freight, gateways and mega-urban regions: the logistical integration of the Bostwash corridor. Tijdschrift voor Economische en Sociale Geografie. 95 (2), $147-$ 161. 
Rodrigue, J-P., Debrie, J., Fremont, A., Gouvernal, E., 2010. Functions and actors of inland ports: European and North American dynamics. Journal of Transport Geography. 18 (4), 519-529.

Rodrigue, J-P., Notteboom, T., 2009. The terminalisation of supply chains: reassessing the role of terminals in port/hinterland logistical relationships. Maritime Policy \& Management. 36 (2), 165-183.

Rodrigue, J-P., Notteboom, T., 2010. Comparative North American and European gateway logistics: the regionalism of freight distribution. Journal of Transport Geography. 18 (4), 497-507.

Rodrigue, J-P, Notteboom, T., 2012. Dry ports in European and north American intermodal rail systems: two of a kind? Research in Transportation Business \& Management.5, 415.

Rodrigue, J-P., Debrie, J., Fremont, A., Gouvernal, E., 2010. Functions and actors of inland ports: European and North American dynamics. Journal of Transport Geography. 18 (4), 519-529.

Rodrigue, J-P, Wilmsmeier, G., 2013. The Benefits of Logistics Investments: Opportunities for Latin America and the Caribbean, Washington DC: Inter-American Development Bank.

Rodríguez-Pose, A., Gill, N., 2003. The global trend towards devolution and its implications. Environment \& Planning C,21(3), 333-351.

Roso, V., 2008. Factors influencing implementation of a dry port. International Journal of Physical Distribution \& Logistics Management. 38 (10), 782-798.

Roso, V., Woxenius, J., Lumsden, K., 2009. The dry port concept: connecting container seaports with the hinterland. Journal of Transport Geography. 17 (5), 338-345.

Sánchez, R., Wilmsmeier, G., 2010. Contextual Port Development: A Theoretical Approach. In: Coto-Millán, P., Pesquera, M., Castanedo, J. (Eds.),Essays on Port Economics (1st ed.), New York: Springer, pp. 19-44).

Schober, H., 1991. Irritation und Bestätigung - Die Provokation der systemischen Beratung oder: Wer macht eigentlich die Veränderung? In: M. Hofmann (Ed.),Theorie und Praxis der Unternehmensberatung, Heidelberg, p. 352

Simatupang, T. M., Sridharan, R., 2002. The collaborative supply chain. International Journal of Logistics Management. 13 (1), 15-30. 
Skjoett-Larsen, T., Thernøe, C., Andresen, C., 2003. Supply chain collaboration: theoretical perspectives and empirical evidence. International Journal of Physical Distribution and Logistics Management. 33 (6), 531-549.

Slack, B. 1993. Pawns in the game: ports in a global transport system. Growth and change. 24 (4), 579-588.

Slack, B., 1999. Satellite terminals: a local solution to hub congestion? Journal of Transport Geography. 7 (4), 241-246.

Slack, B., 2007. The terminalisation of seaports. In: Wang, J., Olivier, D., Notteboom, T., Slack, B., (Eds.),Ports, Cities and Global Supply Chains. Aldershot: Ashgate.

Slack, B., Wang, J. J., 2002. The challenge of peripheral ports: an Asian perspective. Geojournal. 56 (2), 159-166.

Strambach, S., 2010. Path dependency and path plasticity: the co-evolution of institutions and innovation - the German customized business software industry. In:R Boschma, $\mathrm{R}$ Martin (Eds.), Handbook of Evolutionary Economic Geography, Cheltenham, Edward Elgar, pp. 406-431.

Swyngedouw, E., 2000. Authoritarian governance, power and the politics of rescaling. Environment \& Planning D. 18 (1), 63-76.

Taaffe, E. J., Morrill, R. L., Gould, P. R., 1963. Transport expansion in underdeveloped countries: a comparative analysis. Geographical Review, 53, 503-529.

Trip, J., Bontekoning, Y., 2002. Integration of small freight flows in the intermodal transport system. Journal of Transport Geography. 10 (3), 221-229.

Tsamboulas, D., Vrenken, H., Lekka, A-M., 2007. Assessment of a transport policy potential for intermodal mode shift on a European scale. Transportation Research Part A, 41, 715733.

Tuominen, M., 2004. Channel collaboration and firm value proposition. International Journal of Retail and Distribution Management. 32 (4), 178-189.

UNCTAD, 1992. Development and improvement of ports: the principles of modern port management and organisation, Geneva: UNCTAD.

Van den Berg, R., De Langen, P. W., 2011. Hinterland strategies of port authorities: a case study of the port of Barcelona. Research in Transportation Economics. 33(1), 6-14.

Van den Berg, R., De Langen, P. W., Costa, C. R., 2012. The role of port authorities in new intermodal service development: the case of Barcelona Port Authority. Research in Transportation Business \& Management. 5: 78-84. 
Van der Horst, M. R., De Langen, P. W., 2008. Coordination in hinterland transport-chains: a major challenge for the seaport community. Maritime Economics \& Logistics. 10 (1-2), 108-129.

Van der Horst, M. R., Van der Lugt. L. M., 2009. Coordination in railway hinterland chains: an institutional analysis. Paper presented at the International Association of Maritime Economists (IAME) conference, Copenhagen, June 2009.

Van der Horst, M. R., Van der Lugt, L. M., 2011. Coordination mechanisms in improving hinterland accessibility: empirical analysis in the port of Rotterdam. Maritime Policy \& Management. 38 (4), 415-435.

Van de Voorde, E., Vanelslander, T., 2009. Market power and vertical and horizontal integration in the maritime shipping and port industry. JTRC OECD/ITF Discussion Paper 2009-2.

Van Klink, H. A., 1998. The port network as a new stage in port development: the case of Rotterdam. Environment and Planning A. 30 (1), 143-160.

Veenstra, A., Zuidwijk, R., van Asperen, E., 2012. The extended gate concept for container terminals: expanding the notion of dry ports. Maritime Economics \& Logistics. 14 (1), 14-32.

Wang, C., Ducruet, C. 2012. New port development and global city making: emergence of the Shanghai-Yangshan multi-layered gateway hub. Journal of Transport Geography. 25, 58-69.

Williamson, O. E., 1975. Markets and Hierarchies: Analysis and Antitrust Implications, New York: The Free Press.

Williamson, O.E., 1985.The Economic Institutions of Capitalism, New York: The Free Press.

Wilmsmeier, G., Monios, J. 2013. Counterbalancing peripherality and concentration: an analysis of the UK container port system. Maritime Policy \& Management, 40, 116-132.

Wilmsmeier, G., Monios, J., Lambert, B., 2010. Observations on the regulation of "dry ports" by national governments. Paper presented at the annual conference of the International Association of Maritime Economists (IAME), Lisbon, July 2010.

Wilmsmeier, G., Monios, J., Lambert, B., 2011. The directional development of intermodal freight corridors in relation to inland terminals. Journal of Transport Geography, 19, 1379-1386.

Wilmsmeier, G., Monios, J., Perez, G. 2013. Port system evolution - the case of Latin America and the Caribbean. Paper presented at the annual conference of the International Association of Maritime Economists (IAME). Marseille, France, July 2013. 
